\title{
Haptic simulators with virtual reality environments in dental education: A preliminary teaching diagnosis.
}

\author{
Gleyvis Coro Montanet \\ gleyvis.coro@universidadeuropea.es \\ Universidad Europea \\ Margarita Gómez Sánchez \\ margarita.gomez2@universidadeuropea.es \\ Universidad Europea \\ Ana Suárez García \\ ana.suarez@universidadeuropea.es \\ Universidad Europea
}

Fecha presentación: 13/10/2016 | Aceptación: 10/04/2017 |Publicación: 23/06/2017

\section{Resumen}

Se realizó un estudio descriptivo-exploratorio con una muestra de 22 profesores de odontología de la Universidad Europea con destacada trayectoria en simulación. Se integró una comunidad de prácticas de aprendizaje colaborativo con tres simuladores que combinaban interfaces hápticas y de realidad virtual, y se aplicó un cuestionario postexperimental para evaluar la acogida docente de los Simodont -desarrollados por Moog y Academic Centric for Dentistry Amsterdam, ACTA-, dispuestos para ser introducidos en la docencia de la titulación. Para el análisis de datos se utilizó un software SPSS V.21.0 y estadígrafos de media, desviación típica y correlación. Se elaboraron tablas, aplicando pruebas de Kolmogorov-Smírnov y de Kruskal-Wallis, con un nivel de significación de 95\%. Se obtuvo como resultados que las aportaciones educativas de Simodont superaban las prestaciones técnicas. Se describió una relación inversa entre las variables edad y facilidad de manejo del simulador. Se evidenció que el manejo de la tecnología de vanguardia decrece a medida que aumenta la edad de los docentes, lo que indicó la necesidad de formar al profesorado en el manejo de la tecnología y en la introducción de métodos didácticos innovadores para el mejor aprovechamiento de las oportunidades básicas y adicionales que ofrece el simulador.

Palabras clave: realidad virtual; simulador háptico; educación dental; aprendizaje interactivo; ergonomía; simulador; 3D.

\section{Resum}

Es va realitzar un estudi descriptiu-exploratori amb una mostra de 22 professors d'odontologia de la Universitat Europea amb una destacada trajectòria en simulació. Primer, es va crear una comunitat de pràctiques d'aprenentatge col-laboratiu amb tres simuladors que combinaven interfícies hápticas i de realitat virtual, i es va aplicar un qüestionari post-experimental per avaluar l'acollida docent dels Simodont -desarrollados per Moog i Academic Centric for Dentistry Amsterdam (ACTA)-, disposats per ser introduïts en la docència de la titulació. Per a l'anàlisi de dades es va utilitzar un programari SPSS versió 21 i estadígrafs de mitjana, desviació típica i correlació dels resultats. Es van elaborar taules, aplicant proves de Kolmogorov-Smirnov i de Kruskal-Wallis, amb un nivell de significació de 95\%. Es va obtenir com a resultats que les aportacions educatives de Simodont superaven les prestacions tècniques. Es va descriure una relació inversa entre les variables edat i facilitat de maneig del simulador. Es va evidenciar que el maneig de la tecnologia d'avantguarda comença a decréixer des de primerenques edats docents, el que va indicar la necessitat de formar el professorat en el maneig de la tecnologia i en la introducció de mètodes didàctics innovadors per al millor aprofitament de les oportunitats bàsiques i addicionals que ofereix el simulador.

Paraules clau: educació dental; ergonomía; simulador hàptic; aprenentatge interactiu; realitat virtual; 3D. 
Coro Montanet, Gleyvis; Gómez Sánchez, Margarita; Suárez García, Ana. “Haptic simulators with virtual reality environments in dental education: A preliminary teaching diagnosis”. @tic. revista d'innovació educativa. Número 18. Primavera (Enero-Junio 2017), pp. 14-21.

\begin{abstract}
A descriptive exploratory study was performed at the Universidad Europea with a sample of 22 professors of dentistry with a distinguished career in simulation. A community of practice was created for collaborative learning using the Simodont ${ }^{\circledR}$ Dental Trainer, a dental training simulator developed by Moog and the Academic Centre for Dentistry Amsterdam (ACTA) that combines haptic and virtual reality interfaces. A post-experimental questionnaire was administered to assess the performance of the Simondont ${ }^{\circledR}$ and to determine whether or not the professors would be willing to incorporate it into their curriculum. IBM SPSS Statistics V21.0 software was used for the data analysis and statistics of mean, standard deviation and correlation of the results. Tables were developed applying KolmogorovSmirnov and Kruskal-Wallis tests, and the established level of significance was 95\%. The results indicated that the educational contributions of the Simodont ${ }^{\circledR}$ exceeded its technical features. An inverse relationship was described between the variables Age and Ease of use of the simulator. It became apparent that the use of state-of-the-art technology begins to decrease as teaching age increases. This indicated the need to train faculty in the use of the technology and in the introduction of innovative teaching methods to make the best use of the basic and additional opportunities the simulator offers.
\end{abstract}

Keywords: virtual reality; haptic simulator; dental education; interactive learning; ergonomics; simulator; 3D

\section{Introduction}

A dentist is a professional who, on a daily basis, executes invasive actions in small operative fields that are improperly or poorly lit and plagued with microorganisms. This is done with sharp instruments moving at high speeds. The pedagogical solution that schools found to ensure significant learning on the part of the student as well as protection for the future patient was the preclinical application of methods that would recreate reality with simulators installed in spaces that imitated clinics (Núñez et.al, 2012).

With an approach that recalls Freinet's (1896-1996) contributions to the field of basic education, dental pedagogy was compelled to introduce the clinic into the classroom as the best learning strategy to shorten the existing gap between theory and practice. Thus, Dental Schools built preclinical laboratories and dedicated several academic courses to practical exercise with simulators. In the beginning, students worked with inert objects such as plastic models that imitated human jaws. Subsequently these were inserted into a human-like doll that adopted positions similar to those of the patient.

These dummies had articular and adjustable possibilities in the mouth opening and the positions of the head, neck and torso. This made it possible to develop ergonomic skills, to adjust the positions of the patient/operator and to practice treatments on models assembled in dental arcades (thypodonts) and accessible through rubber holes that simulated an open mouth.

Over time, suction systems, rotary instruments and water and air syringes were added to the manikins which improved the students' sense of reality and prepared them better, vis-à-vis their performance in real-world scenarios.

In this way, students were provided with a safe learning environment where they could perform erroneous actions without incurring unfavorable consequences for the patient or themselves.

But the development of new technologies and the gap between learning with synthetic models that were nothing like real oral structures accentuated the need to seek better alternatives (Boer et al., 2013).

Extracted human teeth were used in an attempt to create a more realistic operative experience, but there were obvious microbiological concerns in their preparation. Moreover, as the quality of life and prevention techniques in the developed regions of the planet improved, dental extractions decreased, and consequently natural teeth with preserved structures were scarcer. This opened the way for these more technologically advanced regions to begin to develop innovations to replace conventional simulators with simulators paired with systems that provided new technologies (Tanzawa et al., 2009; Tanzawa et al., 2012).

These new simulators became more and more accessible as the operating systems for computers, smart phones and tablets were being developed and the new generations took advantage of a newly formed language of digital codes linked to terminals with interfaces that allowed them to interact with the apparatus manually (Hung, 2001).

Luciano, Banerjee y DeFanti (2009), reviewed the technological evolution of medical and dental simulators. They created a progress list of simulators that starts with the models with computer assisted pneumatic systems, consisting of manikins connected to computers via an infrared camera attached to the hand piece, and ends with the haptic models, considering these to be state-ofthe-art.

Luciano et al., (2009) and Boer, Bakker, Wesselink y Vervoorn (2012) believe haptic simulators are much more cost-effective for the student because they solve the need to invest in physical models and rotary instruments and they contribute to the universities' economic and environmental sustainability by providing clean virtual pathological environments.

Articles reviewed address the generation of models that take advantage of virtual reality (Buchanan, 2004); others describe the advantage of combining virtual reality programs with a haptic feedback interface (Rhienmora et al., 2010). Namely, a three-dimensional pencil type haptic device that allows the user to experience very realistic sensory feedback when touching computer generated objects.

\subsection{Moog Simodont ${ }^{\circledR}$ Dental Trainer (Simodont ${ }^{\circledR)}$}

This model was first used by the Academic Centre for Dentistry Amsterdam (ACTA) in September 2010 (Boer et al., 2012).

The current units have evolved into a design that consists of a main ergonomic column, where there is a haptic interface and, above this field, a 3D projection screen, both scenarios positioned where the patient's head is normally located.

The 3D virtual environment (3D viewer), requires the use 
Coro Montanet, Gleyvis; Gómez Sánchez, Margarita; Suárez García, Ana. “Haptic simulators with virtual reality environments in dental education: A preliminary teaching diagnosis”. @tic. revista d'innovació educativa. Número 18. Primavera (Enero-Junio 2017), pp. 14-21.

of black anaglyph glasses so the operator can perceive the depth of the image (tooth, dental arcade or training object).

The operator is then immersed in a multi-screened canopy of visual capabilities, manual skills and auditory sensations accompanied by an acoustic module with adjustable volume that reproduces the sound of the actual devices and synchronizes the guiding hand and the foot on the pedal that controls the speed of the drill. These maneuvers reproduce the actual situation he will carry out later with the patient in the clinic and reproduce the systems of previous simulators (Rose, Buchanan y Sarret, 1999) with the additional benefit that, with Simodont ${ }^{\circledR}$, there is no expense for drills or water and the rotors of the handpieces don't experience the wear and tear caused by plastic teeth (Boer et al., 2013).

The manual sensory interaction with the haptic field is accompanied by the display on the 3D screen and is combined with the display/interaction with the touch screen, screen-user integration terminal/courseware where the haptic and the virtual are selected and that provides magnified video feedback to the instructor as well (Bakr et al., 2013).

Also, for the development of the initial skills of muscle control, pressure regulation and length of the cut, prototypes of virtual cubes have been designed with areas ready for grinding and danger areas that should be retained that provide a score that assesses the student's manual dexterity (Bark et al., 2013).

Figure 1 details the design elements and structures of the simulator (MOOG, 2012) and Figure 2 describes the elements identified in the infographic:

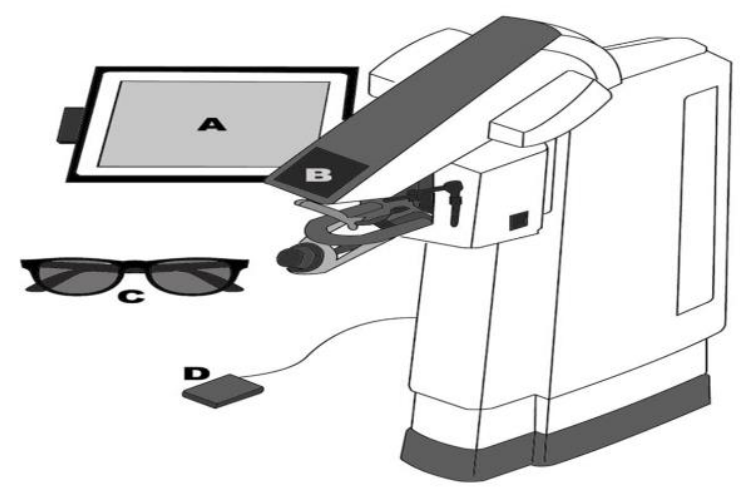

Figure 1. Moog Simodont ${ }^{\circledR}$ Dental Trainer. Picture courtesy of A. Suárez, by written permission.

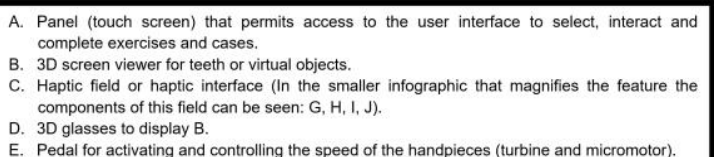

Figure 2. Legend of Simodont $\AA^{\circledR}$ components. Translated from User Manual. Moog Simodont ${ }^{\circledR}$ Dental Trainer (2012), with contributions from the authors of this research.

The most substantive advance offered by the haptic models is to give the sensation of operating on real teeth with virtual pathology, enabling students to differentiate between disease conditions that are not reproduced in the plastic models and eliminating the contaminant factor of extracted teeth (Bakker et al., 2010).

Without pathological insinuations, the student faces the preparations ignoring the limits of the carious lesion, without knowing with certainty the distribution, in terms of breadth and depth, of the dental disease.

As devised, the coursewares can easily be adapted to role-playing by including a virtual waiting room with patients with different treatment needs. This calls for the necessary "fiction contract" that should be established between the team, the student and the teacher to develop a highly realistic simulation (Boer et al., 2012; Dieckman et al., 2007).

The simple dynamic design of the interface allows the student to select cases, develop the clinical method with the aid of x-rays and photos of the pathology and the complete structure of the tooth and incorporate elements of the medical history, select the instruments and the diagnostic tests, situate the tooth depending a greater or lesser degree of manual ability and of direct or indirect vision, through the use of the mirror.

On the other hand, human error, which in a clinic represents a critical moment for the patient's heath and the student's performance and, in the conventional manikins, involves replacing one tooth with another, is easily repairable with Simodont ${ }^{\circledR}$. According to Boer et al., it can be reversed with the simple press of a button, which also reduces material costs and, through the unlimited repetition of the maneuver, prevents consequences of negative significance such as iatrogenesis (Boer et al., 2012).

Simodont ${ }^{\circledR}$ provides additional opportunities that are derived from its combination with an intelligent operating system. It offers the opportunity to assess the workpiece through a system of standardized measurement that rates the drilling in the permitted and non-permitted wear areas and takes and saves images of the tooth preparation, the work in the arcades in the virtual cube or above the cylindrical forms of virtual lab at different times. This makes it possible to verify how the student is evolving (Bakker et al., 2010).

Given these features, Boer et al. point out that, since its release date, so far Simodont ${ }^{\circledR}$ has aroused the interest of the dental world beyond the Netherlands and consequently is already found in dental faculties in the United States, Spain, Germany, the United Kingdom, Saudi Arabia, Australia, China, Turkey, Brazil and Chile (Boer et al., 2012).

\subsection{How virtual teeth are generated in Simodont ${ }^{\circledR}$}

According to Boer et al., virtual teeth are created from the scan of a real tooth using a Dental Cone Beam Computed Tomography (CBCT). The image that is obtained from this process produces a tooth with multiple gray scales and the precise anatomy of all surfaces (Boer et al., 2013).

The ColorMapEditor program merges the different dental faces obtained from the scan and produces a threedimensional tooth that can be modified in volume and color and for which a virtual dental arcade can be produced. And, through 3D editing, it permits manipulation of the density to adjust the hardness of the surfaces; it even reproduces the soft consistency of the carious lesion. Also, if virtual gaps occur during the scanning of the tooth they can be corrected by adding virtual tissue when manipulating the density (Boer et al., 2013).

In this way, the software that generates the virtual teeth 
Coro Montanet, Gleyvis; Gómez Sánchez, Margarita; Suárez García, Ana. “Haptic simulators with virtual reality environments in dental education: A preliminary teaching diagnosis”. @tic. revista d'innovació educativa. Número 18. Primavera (Enero-Junio 2017), pp. 14-21.

is capable of creating teeth with the greatest number of structural and pathological variations, which makes it possible to have a repository of cases available for teaching (Boer et al., 2013).

\subsection{Simodont ${ }^{\circledR}$ and future trends}

The spearhead in the prospective development of this simulator is in the need to generate a greater number of programs for the pathologies that as yet cannot be addressed.

In periodontal treatments, haptic technology can yield excellent results because it is a specialty whose abnormalities are especially detected and treated through tactile sensations (Millikarjun et al., 2014).

We can also foresee that the more complex treatments, the less frequent cases that are rarely seen in the clinic and thus, that the student may graduate without having experienced, can be introduced and treated.

There is one substantial limitation that it would be necessary to overcome when it comes to generating working jaws. And that is, according to Boer et al., that because the equipment's haptic memory is limited, it isn't possible to reproduce the sense of touch for all of the teeth in a complete dental arcade.

Similarly, it would be important to develop additional features for the introduction of interfaces that are not limited to the effect of a pencil tip and succeed in attaching haptic devices that will allow the user to feel the contours of bony and three-dimensional mucous structures, using elements known as CyberGloves (Boer et al., 2013).

In view of the multiplicity of opportunities offered by this state-of-the-art technology, we decided to carry out the present study in order to assess the professorial approval of the haptic simulation and virtual reality introduced in the teaching of dentistry at the Universidad Europea.

\section{Material and method}

\subsection{Definition of population and sample}

A survey study was conducted with professors from the department of Dentistry of the Universidad Europea.

Of the total population of 45 practicing instructors, we selected 22 professors with prominent careers in the preclinical and clinical areas. A learning community was formed that was focused on the completion of classroom and virtual exchanges through virtual campus plaatform to document and collaboratively train the sample in the use of the Simodont ${ }^{\circledR}$.

The pooling of criteria on simulation with state-of-the-art technology was carried out in order to standardize criteria on a practically unexplored issue in the field of training in dentistry.

\subsection{Tool for collecting data. Units of analysis and} definition of variables

The teaching sample was scheduled for an initial practice contact with 3 Simodont ${ }^{\circledR}$ simulators. (Figure 3).

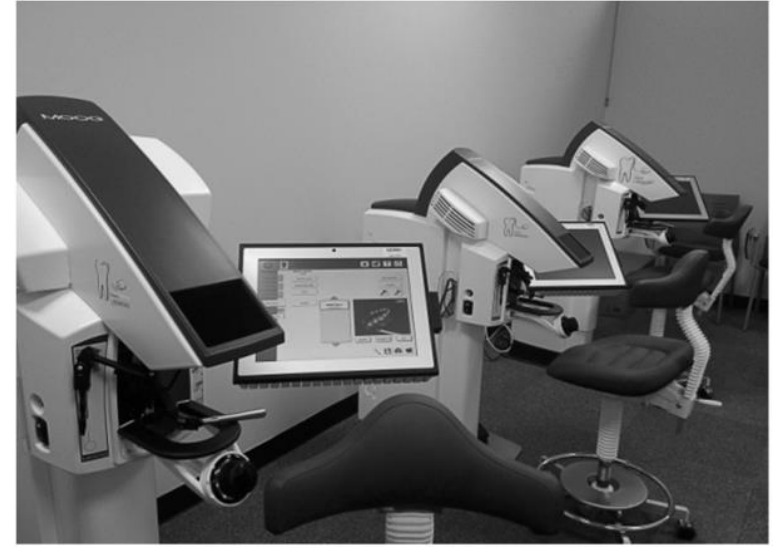

Figure 3. Simodont ${ }^{\circledR}$ Equipment

After consulting similar studies and with the consensus of the research group, a minimum of 30 minutes of training was established. A survey was administered immediately after the initial experience.

The variables were grouped into four thematic units, which are listed in Figure 4.

Fig. 4. Category of indicators.

A) General characteristics of the respondent.

B) Instructor satisfaction about the usefulness of SIMODONT' in cl inical practice.

C) Comparison of SIMODONTe with traditional simulation systems.
A.
1. Sex
2. Age
3. Teaching Experience (years)
4. Trainingtimewith SIMODONT
5. Teaching subject
6. Teaching area (Predinical, Clinical, Both)
1. Realism of touch and cuttingpressure
2. Realism of the turbine
3. Realism of the micromotor
4. Realism of the mirror
5. Realism of the enamel
6 . Realism of the dentin
7. Realism of the carious /esion
8. Realism of the pedal
9. Realism of the drill/cutting quality
10. Realism in the presentation of cases
c.
1. Ease of use
2. Operator/SIMODONT' Relationship
3. Control of cutting depth
4. Control of length of cut
5. Development of manual skills
6. Development of competencies
7. Ease of assessment
8. Ergonomics
9. Cost savings (Sustainability)

Figure 4. Category of indicators. 
Coro Montanet, Gleyvis; Gómez Sánchez, Margarita; Suárez García, Ana. “Haptic simulators with virtual reality environments in dental education: A preliminary teaching diagnosis”. @tic. revista d'innovació educativa. Número 18. Primavera (Enero-Junio 2017), pp. 14-21.

The questions, Likert scale type, were formulated following a homogeneous structure and the closed polytomous response options were sorted from lowest to highest (1 to 5), without any overlap in the established ranges.

\subsection{Data Analysis}

A computer with IBM SPSS Statistics V21.0 software was used for the data processing as well as, after they were codified, for interpreting the answers using statistics of mean, standard deviation and correlation. Tables, line charts and box and whisker plots were developed.

Before performing the analysis of correlation between the variables Age and Ease of Simodont ${ }^{\circledR}$ use, a Kolmogorov-Smírnov normality test was performed which ruled out their normality. Given that circumstance, the Spearman Rho non-parametric test was used.

To study the significance of the data reflected in the whisker plot and due to their lack of normality, the Kruskal-Wallis test was used.

For these analyzes the level of significance was established at 95\%.

\section{Results}

The sample that was analyzed had an average age of 38 , $77.3 \%$ of the respondents were female, $18.2 \%$ were clinical professors, $36.4 \%$ were preclinical professors and $45.4 \%$ were professors in both scenarios, with a range of ages from 27 to 59 years. Of those, 100\% of the professors who were older than 50 were in the preclinical area, $50 \%$ of the instructors between 40 and 49 years old and $72 \%$ of the professors younger than 40 served in both the preclinical and clinical areas and $75 \%$ of the professors in the clinical area were younger than 40 .

The comparative analysis of means and standard deviations of the indicators of instructor satisfaction (Table 1) describes the preponderance of variables of an educational nature.

Of a total of 19 indicators, most of them (13) were technological. One of the latter, Realism of the carious lesion, was ranked highest, with a mean that was identical to that of the second privileged factor (Ease of assessment), but with a slightly lower standard deviation. Following these two top-ranked variables, in order of teaching preference, were the Development of competencies and the Realism of the cases produced by Simodont ${ }^{\circledR}$.

As can be seen, the means of highest educational impact (Ease of evaluation and Development of competencies) are found in the rating of 4 of the applied Likert scale. This is in the context of the second best assessment out of a possible 5 .

\begin{tabular}{|l|l|l|}
\hline INDICATORS & MEAN & STANDARD DEVIATION \\
\hline Realism of the caries & 4.18. & .66 \\
\hline Ease of assessment & 4.18 & .73 \\
\hline Development of competencies & 4.09 & .81 \\
\hline Realism of the cases & 4.05 & .84 \\
\hline Realism of the contra angle hand piece & 4.05 & .89 \\
\hline Realism of the enamel & 4.00 & .81 \\
\hline Sustainability & 3.95 & 1.17 \\
\hline Realism of the dentin & 3.91 & .81 \\
\hline Realism of touch and cutting pressure & 3.91 & 1.01 \\
\hline Realism of turbine cut & 3.86 & .99 \\
\hline Ergonomics & 3.82 & 1.09 \\
\hline Realism of the pedal in terms of speed & 3.82 & .95 \\
\hline Development of manual skills & 3.77 & 1.15 \\
\hline Realism of the drill cut & 3.73 & .82 \\
\hline Control of length of cut & 3.64 & 1.13 \\
\hline Operator/Simodont $®$ relationship & 3.59 & 1.36 \\
\hline Ease of use of Simodont $®$ & 3.55 & 1.43 \\
\hline Control of cutting depth & 3.50 & 1.14 \\
\hline Realism of the mirror & 3.41 & 1.36 \\
\hline
\end{tabular}

Table 1. Teacher satisfaction with educational and technological indicators.

Table 2 reflects the level of the relationship between Age and the Ease of use on the part of the respondents.

The significance $(p=0.000<0.05)$ shows a strong decreasing relationship between variables. This means that as age increases, the ease of Simodont ${ }^{\circledR}$ use decreases.

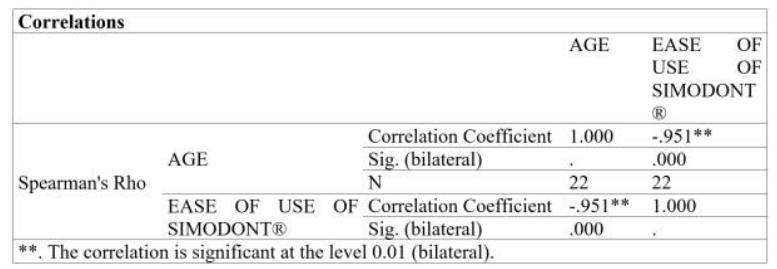

Table 2. Relationship between age of instructors and ease of Simodont ${ }^{\circledR}$ use.

The relationship between both variables can best be explained with the bar graph of both variables (Figure 5), where the rise of the Ease of handling is observed in the $x$-axis; as the Age of the instructors decreases in the $y$ axis. For this result, we segmented the database according to the variable Ease of Simodont ${ }^{\circledR}$ Use, and related this segment with the average of the ages of the instructors, obtaining the age distributions labeled in the columns.

The result that stands out is that the group of instructors with worst Ease of use averaged around 56 years of age. 
Coro Montanet, Gleyvis; Gómez Sánchez, Margarita; Suárez García, Ana. “Haptic simulators with virtual reality environments in dental education: A preliminary teaching diagnosis”. @tic. revista d'innovació educativa. Número 18. Primavera (Enero-Junio 2017), pp. 14-21.

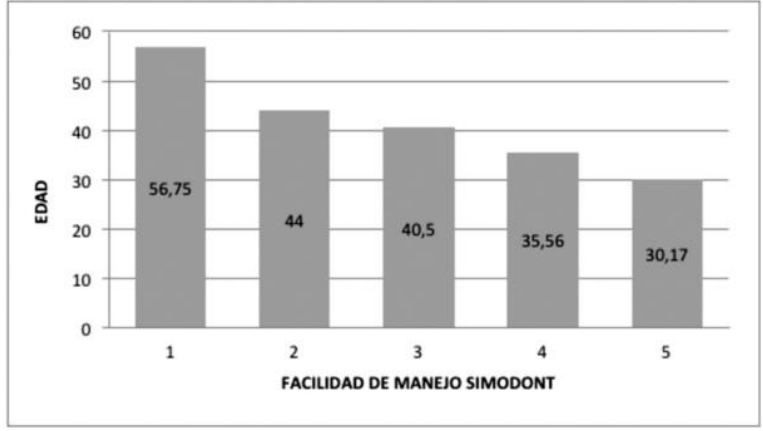

Figure 5. Relationship between the age of the instructors and ease of Simodont ${ }^{\circledR}$ use

The Table 3 groups together the performances of the better assessed variables regarding Instructor performance, which describes whether the professor respondent carries out his/her teaching in Preclinical, Clinical or both, according to the distribution of the means.

Ease of use was also selected because it constitutes an indispensable competency for the achievement of the educational goals. And the teaching behavior according to the performances was compared to determine if this condition influenced the assessment of these variables.

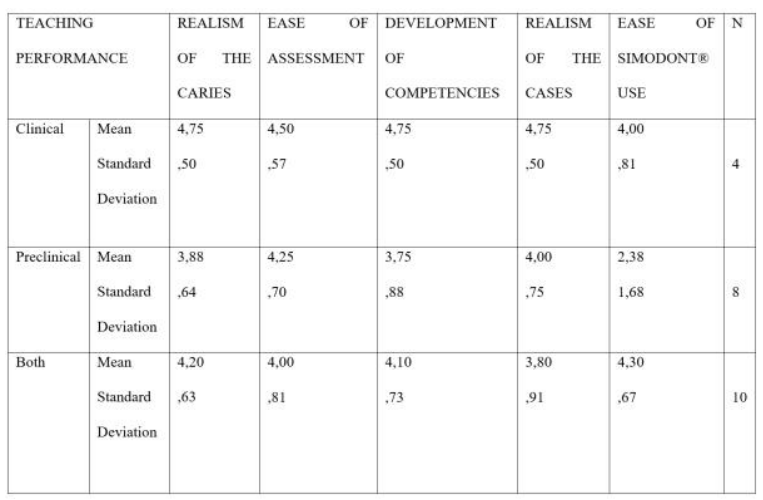

Table 3. Behavior of the highest rated indicators regarding teaching performance.

The best distribution of the variable Realism of the caries, was found in the assessments of the professors in the clinical area, who favorably endorse the haptic property. The preclinical professors were the ones who expressed the worst considerations in regard to this variable.

The Ease of assessment was also more highly rated by the clinical instructors, followed by the preclinical and those of mixed performance. The Development of competencies and the Realism of cases were equally valued by the clinical instructors with high ratings. The Ease of use presented more favorable distribution in the group of instructors with dual performance and its worst results were found among the preclinical instructors.

All the variables in the analysis were subjected to the Kruskal Wallis test, and the Realism of the caries $(p=0.091)$, the Realism of assessment $(p=0.523)$, the Development of competencies $(p=0.134)$, as well as the Realism of the cases $(p=0.137)$ did not show statistically significant differences. Although the closeness to the significance of the Realism of the caries and of assessment does infer that perhaps with a larger sample, the results would have been significant.

For the variable Ease of Simodont ${ }^{\circledR}$ use, the test offers a significant value $(p=0.048)$. But because it is known that $100 \%$ of the respondents older than 50 were the ones who were only teaching preclinical, to delete the age confounder, the test was conducted with those younger than 50 , resulting in a significance of $p=0.65$, which led to the conclusion that the differences among the three groups in the use of the high-tech simulator was marked by the concentration of participants older than 50 in the preclinical group.

The distribution of the means toward the positive side of the scale speaks well of the teaching assessments about these parameters.

\section{Discussion}

Taking into account the results obtained in this study, it is possible to establish comparisons with similar investigations. In a study and diagnosis performed by Bakr et al., with a sample of 11 volunteer instructors who used 60 minutes for the contact with Simodont ${ }^{\circledR}$ and to respond to the forms, it was verified that 70 per cent of the instructors considered, similarly to our study, that the main advantages of the simulators were in their educational contributions (evaluative), while the limitations they observed were mostly technical issues.

The partial results in terms of technical aspects such as the realism of the haptic feedback of tissues, offered larger means (better) and smaller standard deviations in our study. Consequently, it was concluded that our sample's satisfaction with the technical aspects was higher than that of the sample of the study in comparison.

In another preliminary assessment analysis of the use of haptic technology in periodontics, although not for Simodont ${ }^{\circledR}$, but considered because of its historical repercussions and its similarity in the combination of haptic and virtual reality interfaces, Luciano et al. administered a questionnaire with scale questions to a sample of 18 instructors and 5 students, after an initial contact for 10 minutes with the periodontal simulator, developed by the University of Illinois (Luciano et al., 2009).

Of the total of 23 users in their sample, only 2 reflected a little difficulty with the ease of Simodont ${ }^{\circledR}$ use on the surveys, which was solved by extending the work time with the simulator.

Luciano did not assess didactic aspects, only technical ones. And the best relationship of his sample with the haptic simulator could find justification in a greater ease of use of the haptic's instrument in periodontal treatments, when for the procedures that were measured in our study, there was a greater complexity, and a larger cases arsenal, which made it's interface more painstaking.

Although there are studies performed on groups of students with Simodont ${ }^{\circledR}$, for the discussion and comparation were selected samples of teachers because they were considered more similar to each other and their mismatches more significant.

Koopman \& Vernoon point out that the introduction of state-of-the-art technology in dentistry is marked by the fact that the current education is provided in large measure by instructors who grew up before the information and communications revolution, and who may not properly assimilate the introduction of 
Coro Montanet, Gleyvis; Gómez Sánchez, Margarita; Suárez García, Ana. “Haptic simulators with virtual reality environments in dental education: A preliminary teaching diagnosis”. @tic. revista d'innovació educativa. Número 18. Primavera (Enero-Junio 2017), pp. 14-21.

technological innovations (Koopman y Vervoorn, 2012). In our sample, the average ages in which the best results in terms of ease of use were evident, 4 and 5 on the Likert scale, fall in the range of 30 to 35 years, which is consistent with the studies reviewed. Although the existence of means of 40 to 44 years with unfavorable qualities of use ( 2 and 3 on the scale) reflects that the technology is also difficult, at least in the beginning, for a teaching generation that is located at the gates of the technological revolution and which boasts a considerable experience in using it.

In the shadow of these adverse factors, it is even more significant that the sample considers Simodont ${ }^{\circledR}$ as a tool with significant training contributions. That the professors surveyed assess favorably the training component above their own limitations in use, confirms that, as Feeney, Reynolds, Eaton, \& Harper assert, all the technologies used in dental education have strengths and weaknesses. (Fenney et al., 2008).

Another preliminary study performed in the Academic Centre for Dentistry Amsterdam (ACTA) by Vervoorn \& Wesselink describes 10 clinical instructors and 25 clinical dentists linked to traditional preclinical training, who carried out a contact exercise with Simodont ${ }^{\circledR}$ and afterwards filled out a questionnaire (Vervoorn y Wesselink, 2014).

The assessment of the technical issues was highly satisfactory and describes an $80 \%$ satisfaction with Simodont ${ }^{\circledR}$ as a valuable tool for education, a factor in which it coincides once again with the findings of the present study and the others that were reviewed. However, a different perception of the realism of the technical aspects became apparent in that the clinical practice group, unlike in this study, considered the haptic and virtual elements less realistic than their colleagues in the preclinical sphere. This is a phenomenon that the researchers attribute to the fact that the pattern of reference of these respondents was reality, whereas the professors of preclinical performance used traditional simulators as a reference.

In the present investigation it is a salient fact that the professors of dual performance (preclinical and clinical) are the ones who best handled the state-of-the-art technology. That the professors of dual performance (clinical and preclinical) were the ones who used the Simodont $\AA$ best, with a proven statistical significance, is an encouraging result from the training point of view and could be justified because the combination of their professional practice provides them with a greater ability to assimilate innovation in the teaching arena because they have incorporated the new technologies in their daily clinical practice.

The professors of dual performance are the hinge/instructors and their level of Simodont ${ }^{\circledR}$ assimilation is critical for the reduction of the preclinicalclinical gap. On the other hand, the fact that the instructors of the clinical area are the ones that appreciated the educational benefits of the Simodont ${ }^{\circledR}$ more can be compared to the previous result in terms of the ability of the clinical professor to detect the benefits of new technologies, but the lesser assimilation of the preclinical instructors, called to make greater use of the simulator, is perplexing, which is justified statistically by the concentration of professors over 50 in this stratum and is combined with their apparent difficulty in the use of the technology, which can lead them to undervalue the opportunities that Simodont $\AA$ offers.
The fact that the Kruskal Wallis test is not significant for most of the variables can be interpreted as that the behaviors between the teaching performance are not very different from each other. Therefore, from the statistical point of view, being clinical, preclinical, or both has no affect in our investigation.

Nevertheless, the ease of use begins to decrease after early teaching ages. Which indicates that

the lack of training in matters of technology must be observed and repaired through different ways of solutions. Given the fact that the real mastery of technology in education, involves not only the management of the purely technological, but rather, above all, the development of a truly didactic concept of application of what is innovative. A need that is accentuated when the technology that is introduced is new, even for the generation born after 1980, the socalled "digital natives", and when the need for mastery of virtual and haptic interfaces is added to the need to incorporate them with the highest educational budgets so that they produce their greatest services.

Therefore, the design of the educational environment and the learning experience is more important than the technology itself, no matter how novel and beneficial it is. When the simulator has interactive features, the process is more complicated and at the same time more enriching and it is important that the simulation instructor be sufficiently perceptive so as to not waste any of the simulator's additional benefits and create opportunities for meaningful learning, focused on taking advantage of the basic opportunities and the additional ones.

That is why the necessary training of instructors in the use of the technology and in the didactic conditions of its use is the main recommendation of this study. Because, although there are considerable differences in the way the instructor-student relationship is seen in different countries, the research performed allows us to corroborate that the criteria with regard to Simodont ${ }^{\circledR}$ are not so different in the countries that use the technology. This homogenizing element, based on the necessary exchange and the implementation of effective simulations, will enable the growth of the participants in their respective roles.

\section{Conclusions}

After analyzing the results of the study, it is possible to conclude:

- The teaching sample considered that the Simodont ${ }^{\circledR}$ 's educational contributions exceeded its technical features.

- An inverse relationship was described between the variables Age and Simodont $\AA$ Ease of use.

- The need for faculty training in the use of the new technology and in the didactic approach to its use became apparent.

\section{Bibliography}

Bakker, D.; Lagerweij, M.; Wesselink, P. \& M., Vervoorn, (2010) "Transfer of manual dexterity skills acquired on the Simodont, a dental haptic trainer with a virtual environment, to reality. A pilot study", Bio-Algorithms and Med-Systems, 6 (11), pp. 21-24. https://pure.uva.nl/ws/files/1491877/145529_Bio Algorithms and Med_Systems 6 11_21 24.pdf

Bakr, M.M.; Massey, W.L. \& Alexander, H. (2013) "Evaluation of Simodont Haptic 3D virtual reality 
Coro Montanet, Gleyvis; Gómez Sánchez, Margarita; Suárez García, Ana. “Haptic simulators with virtual reality environments in dental education: A preliminary teaching diagnosis”. @tic. revista d'innovació educativa. Número 18. Primavera (Enero-Junio 2017), pp. 14-21.

dental training simulator", International Journal of Dental Clinics, 4 (4), pp. 1-6. http://intjdc.org/index.php/intjdc/article/view/5401. 824

Boer, I.R.; Bakker, D.R.; Wesselink, P.R.; Vervoorn, J.M. (2012) "De Simodont in het onderwijs", Ned Tijdschr Tandheelkd, 112, pp.294-300. DOI: 10.5177/ntvt.2012.06.12105

Boer, I.R.; Wesselink, P.R. \& Vervoorn, J.M. (2013) “The creation of virtual teeth with and without tooth pathology for a virtual learning environment in dental education" Eur J Dent Educ 17 (4), pp.191-197. DOI: http://dx.doi.org/10.1111/eje.12027

Buchanan, J., (2004) "Experience with Virtual Reality Based Technology in Teaching Restorative Dental Procedures" J Dent Ed., 68 (12), pp. 1258-1265. https://www.ncbi.nlm.nih.gov/pubmed/15576814

Dieckman, P.; Gaba, D. \& Rall, M. (2007) “Deepening the Theoretical Foundations of Patient Simulation as Social Practice", Simulation in Healthcare, 2 (3), pp. 183-193. DOI: 10.1097/SIH.0b013e3180f637f5

Feeney, L.; Reynolds, A.; Eaton, K.A. \& Harper, A.J. (2004) "A description of the new technologies used in transforming dental education", British Dental Journal, 204 , pp. 19-28. DOI:10.1038/bdj.2007.1185

Hung, D. \& Chen, D.T. (2001) "Situated cognition, Vygotskian thought and learning from the communities of practice perspective: Implications for the design of web-based elearning" Educational Media International, $1 . \quad$ DOI: 10.1080/0952398011003752 5

Koopman, P. \& J.M., Vervoorn J.M. (2012) "Onderwijsinnovaties voor de digitale student". Ned Tijdschr Tandheelkd, 6, pp.286-290. DOI: http://dx.doi.org/10.5177/ntvt.2012.06.12104

Luciano, C.; Banerjee, P. \& DeFanti, T. (2009) "Hapticsbased virtual reality periodontal training simulator. Virtual reality", Virtual reality, 13 (69). DOI: 10.1007/s10055-009-0112-7

Mallikarjun, S.A.; Tiwari, S.; Sathyanarayana, S. \& Devi,
P.R., (2014) "Haptics in periodontics", J. Indian Soc. Periodontol, 18 (1), pp. 112-113. http://www.jisponline.com/article.asp?issn $=0972-$ 124X;year $=2014 ;$ volume=18;issue=1; spage=112; age $=113$; aulast $=$ Mallikarjun

MOOG, (2012) User Manual. Moog Simodont Dental Trainer. Installation Manual. $\mathrm{N}^{\circ}$ 2.0, pp. 9. Ámsterdam.

Núñez, D.W.; Taleghani, M.; Wathen, W.F. \& Abdellatif, H.M. (2012) "Typodont versus live patient: Predicting Dental Students' Clinical Performance” J Dent Educ., 76 (4), pp. 407-413. https://www.ncbi.nlm.nih.gov/pubmed/22473552

Rhienmora, P.; Haddawy, P.; Khanal, P.; Suebnukarn, M. \& Dailey, M.N. (2010). "A virtual reality simulator for teaching and evaluating dental procedures", Methods Inf. Med., 49 (4), pp.396-405. DOI: 10.3414/ME9310

Rose, J.; Buchanan, J. \& Sarret, D. (1999) "The DentSim System", J Dent Educ., 63 (5), pp. 421-423.

Tanzawa, T. et al., (2013) "Medical emergency education using a robot patient in a dental setting", Eur J Dent Educ, $\quad 13 \quad$ (2), pp.69-85. http://dx.doi.org/10.1007/s10055-009-0112-7

Tanzawa, T.; Futaki, K.; Tani, C.; Hasegawa, T.; Yamamoto, M.; Miyazaki, T. \& Maki, K. (2012) "Introduction of a robot patient into dental education", Eur J Dent Educ, 17 (1), pp.114-119. DOI: 10.1111/j.1600-0579.2012.00770.x

Vervoorn, J. M. \& Wesselink P.R. (2005) "The perception of the level of realism of a dental training simulator (Simodont)" poster de Congreso Academy Centre for Dentistry Amsterdam (ACTA). 13 de abril 2005.

| Cita recomendada de este artículo

Coro Montanet, Gleyvis; Gómez Sánchez, Margarita; Suárez García, Ana. (2017). "Haptic simulators with virtual reality environments in dental education: A preliminary teaching diagnosis”. en @tic. revista d'innovació educativa. Número 18. Primavera (Enero-Junio 2017), pp. 14-21. 